Situs Jurnal : $\underline{\text { http://ejournal.stiepancasetia.ac.id/index.php/jieb }}$

Jilid 5 Nomor 2 Juli 2019

Hal $256-268$

\title{
FAKTOR-FAKTOR YANG MEMPENGARUHI KEPUASAN KERJA KARYAWAN PT. GRAFIKA WANGI KALIMANTAN
}

\section{Periyadi* dan Riris Ambarwati}

Abstract: The main objective in this study is to study and analyze (1) How much influence the job satisfaction factor includes Compensation, Job Characteristics and work morale on Employee Job Satisfaction (2) How much Compensation has an influence on employee job satisfaction (3) How much Characteristics Employment Work Against Employee Job Satisfaction (4) How much morale influences work satisfaction. The targets in this study include (1) Increasing employee work productivity through employee job satisfaction (2) Making guidelines for company leaders to be able to improve employee job satisfaction. This research was conducted with quantitative methods and used analytical methods with SPSS Windows For Data as a data analysis tool.

Keywords: compensation, job characteristic, work morale, job satisfaction

Abstrak: Tujuan utama dalam penelitian ini adalah untuk mengkaji dan menganalisis (1) Seberapa besar pengaruh faktor kepuasan kerja yang meliputi Kompensasi, Karakteristik Pekerjaan dan semangat kerja Terhadap Kepuasan Kerja Karyawan (2) Seberapa besar Kompensasi mempunyai pengaruh terhadap Kepuasan kerja karyawan(3) Seberapa besar Karakteristik Pekerjaan Berpengeruh Terhadap Kepuasan Kerja Karyawan (4) Seberapa besar semangat kerja berpengaruh terhadap kepuasan kerja. Adapun target dalam penelitian ini antara lain (1) Meningkatkan produktivitas kerja karyawan melalui kepuasan kerja karyawan (2) Menjadikan pedoman bagi pimpinan perusahaan untuk dapat meningkatkan kepuasan kerja karyawan. Penelitian ini dilakukan dengan metode kuantitatif serta menggunakan metode analisis dengan SPSS Windows For Data sebagai sebuah alat analisis data

Kata kunci : kompensasi, karakteristik pekerjaan, semangat kerja, kepuasan kerja

\section{Latar Belakang}

PT. Grafika Wangi Kalimantan (GWK) merupakan sebuah perusahaan yang bergerak dibidang percetakan. PT. Garfika Wangi Kalimantan (GWK) menghasilkan produk dan jasa. Produk yang dihasilkan adalah packaging, buku, kalender, undangan, brosur, paperbag, Form, dan lain sebagainya sedangkan jasa yang dihasilkan adalah pelayanan dibidang ekspedisi. Packaging, undangan, buku, dan paperbag merupakan produk unggulan PT. Grafika Wangi Kalimantan (GWK) yang dijadikan sebagai daya tarik bagi konsumen untuk mendapat hasil cetakan dan kualitas yang diinginkan konsumen. Komoditas produk tersebut merupakan modal utama PT. Grafika Wangi Kalimantan (GWK), dalam menjalankan bisnis percetakannya. Oleh karena itu PT. Grafika Wangi Kalimantan (GWK) harus dikelola oleh sumber daya manusia (SDM) yang berkualitas. 
Kepemilikan terhadap SDM yang berkualitas dapat mewujudkan cita-cita perusahaan, yang terdiri dari:

1. Menjadi pusat percetakan khususnya di Kalimantan Selatan yang bermanfaat bagi kemajuan pendidikan dan ilmu pengetahuan dibidang ilmu percetakan.

2. Mencapai laba dan dan pertumbuhan yang memuaskan.

3. Memajukan perusahaan.

4. Menciptakan perusahaan yang tangguh.

5. Membuat karyawan sejahtera.

6. Menjaga citra perusahaan.

7. Membuat brand association PT. Grafika Wangi Kalimantan (GWK) naik.

Setiap perusahaan mempunyai keinginan meningkatkan dan mengembangkan usaha dengan cara yang tersusun dalam program untuk meningkatkan kinerja karyawan, begitu juga hal yang diharapkan oleh pihak PT Grafika Wangi Kalimantan. Terdapat beberapa terkait dengan perbaikan kinerja perusahaan, diantaranya perusahaan kurang menerapkan sistem promosi jabatan, dimana promosi jabatan merupakan salah satu factor untuk dapat meningkatkan prestasi kerja, sehingga karyawan dapat bekerja sesuai target perusahaan, akhirnya memampukan perusahaan untuk bersaing dengan perusahaan lain.

Perusahaan diharapkan mampu menyediakan barang permintaan konsumen yang terjamin kualitas dan kuantitasnya. Semakin banyak perusahaan bergerak dalam bidang produksi maka semakin ketat kompetisi antar perusahaan. Karyawan bagian produksi merupakan sumber daya yang tidak kalah penting dengan sumber daya perusahaan lainnya. Lancar atau tidaknya sebuah proses produksi akan sangat tergantung pada karyawan pelaksana produksi. (Sutrisno, 2009).

Davis dan Newton (2004: 44), kepuasan kerja adalah keadaan emosional yang menyenangkan atau tidak menyenangkan dimana para pegawai memandang pekerjaannya. Berarti kepuasan kerja merupakan hal-hal yang dapat menyenangkan atau perasaan positif yang merupakan akibat dari penghargaan terhadap pekerjaan seseorang. Tingkah laku karyawan yang malas menimbulkan masalah bagi perusahaan berupa tingkat absensi yang tinggi, keterlambatan kerja dan pelanggaran disiplin yang lainnya, tingkah laku karyawan yang puas lebih menguntungkan bagi perusahaan.

Kompensasi menurut Malayu S.P. Hasibuan (2002) adalah semua pendapatan yang berbentuk uang, barang langsung atau tidak langsung yang diterima karyawan sebagai imbalan atas jasa yang diberikan kepada perusahaan.

Tujuan pemberian kompensasi antara lain adalah sebagai ikatan kerja sama, kepuasan kerja, pengadaan efektif, motivasi, stabilitas karyawan, disiplin, serta pengaruh serikat buruh dan pemerintah. Iklim organisasi merupakan suatu karakteristik yang membedakan suatu organisasi dengan organisasi lainnya, mempengaruhi individu individu didalamnya, serta secara relative bertahan dalam jangka waktu tertentu.

Menciptakan iklim organisasi yang mampu membawa anggotanya untuk meningkatkan kinerja dalam rangka pencapaian tujuan organisasi bukanlah hal yang mudah. Hal ini disebabkan karena pada dasarnya manusia memiliki karakteristik tingkah laku yang berbeda sesuai dengan tingkat kebutuhannya (Hakim,2006 : 170).

Dengan semangat kerja yang tinggi maka akan tercipta karyawan yang berprestasi dimana pekerjaan dapat terselesaikan dengan cepat, absensi dapat diperkecil, kerusakan dapat dikurangi dan kemungkinan perpindahan karyawan ke perusahaan lain dapat diperkecil. Semangat kerja dan kepuasan kerja sangat mempengaruhi pencapaian tujuan perusahaan. Jika dalam suatu perusahaan tingkat semangat kerja dan produktifitas rendah maka perusahaan tersebut akan banyak mengalami kesulitan bahkan perusahaan bisa gulung tikar apabila tidak segera ditangani. Salah satu cara untuk mengatasi masalah semangat kerja dalam upaya meningkatkan 
kepuasan kerja karyawan adalah dengan memberikan iklim kerja yang baik dan semangat yang tinggi (Panudju, 2003).

\section{Kajian Literatur}

Sumber daya manusia merupakan salah satu sumber daya yang paling menentukan sukses tidaknya suatu organisasi. Berbeda dengan sumber daya organisasi lainnya, sumber daya manusia merupakan faktor produksi yang memiliki mempunyai pengaruh yang dominan terhadap faktor produksi yang lain seperti mesin, modal, material, dan metode. Oleh karena itu, organisasi dituntut untuk mengelola sumber daya manusia yang dimiliki dengan baik demi kelangsungan hidup dan kemajuan organsiasi.

Dengan demikian keberhasilan dalam proses operasional organisasi sangat ditentukan oleh kualitas sumber daya manusia yang dalam hal ini adalah karyawan. Kontribusi karyawan bagi organisasi sangat dominan, karena karyawan adalah penghasil kerja bagi organisasi. Hal ini berarti adalah setiap pekerjaan dalam organisasi selalu dilaksanakan oleh karyawan. Berhasil tidaknya suatu organisasi ditentukan oleh unsur manusia yang melakukan pekerjaan sehingga perlu adanya balas jasa terhadap karyawan sesuai dengan sifat dan keadaannya. Seorang karyawan perlu diperlakukan dengan baik agar karyawan tetap bersemangat dalam bekerja.

Pimpinan organisasi dituntut untuk memperlakukan karyawan dengan baik dan memandang mereka sebagai manusia yang mempunyai kebutuhan baik materi maupun non materi. Pimpinan organisasi juga perlu mengetahui, menyadari dan berusaha memenuhi kebutuhan karyawannya, sehingga karyawan dapat bekerja sesuai dengan harapan organsiasi.

Sehubungan dengan hal tersebut, Winardi (2002:60) mengatakan bahwa sumberdaya manusia merupakan aktivitas majikan dalam hubungannya dengan para pekerja sebagai individu-individu.

Anwar Prabu Mangkunegara (2005:2) mendefinisikan manajemen sumber daya manusia merupakan suatu perencanaan, pengorganisasian, pengkoordinasian, pelaksanaan dan pengawasan terhadap pengadaan, pengembangan, pemberian, dan pemisahan tenaga kerja dalam rangka mencapai tujuan organisasi.

Menurut Malayu S.P Hasibuan (2013:21) Manajemen SDM merupakan bagian dari manajemen umum yang memfokuskan dari pada SDM. Adapun fungsi-fungsi manajemen SDM, seperti halnya fungsi manajemen umum, yaitu:

1. Perencanaan (planning)

Merencanakan tenaga kerja secara efektif serta efisien agar sesuai dengan kebutuhan perusahaan dalam rangka membantu terwujudnya tujuan.

2. Pengorganisasian (organization)

Kegiatan untuk mengorganisasi semua karyawan dengan menetapkan pembagian kerja, hubungan kerja, delegasi wewenang, integrasi dan koordinasi dalam bagan organisasi.

3. Pengarahan (directing)

Kegiatan mengarahkan semua karyawan agar mau bekerjasama dan bekerja efektif dan efisien dalam membantu terwujudnya tujuan perusahaan.

4. Pengendalian (controlling)

Kegiatan mengendalikan semua karyawan agar mentaati peraturan-peraturan perusahaan dan bekerja sesuai rencana. Apabila terdapat penyimpangan atau kesalahan maka diadakan tindakan perbaikan dan penyempurnaan rencana.

5. Pengadaan (procurement)

Proses penarikan, seleksi, penempatan, orientasi dan induksi untuk mendapatkan karyawan yang sesuai dengan kebutuhan perusahaan.

6. Pengembangan (development) 
Proses peningkatan keterampilan teknik, teoritis, konseptual, dan moral karyawan melalui pendidikan dan pelatihan. Pendidikan dan pelatihan yang diberikan harus sesuai dengan kebutuhan pekerjaan masa kini maupun masa depan.

7. Kompensasi (compensation)

Pemberian balas jasa langsung (direct) dan tidak langsung (inderect), uang atau barang kepada karyawan sebagai imbalan jasa yang diberikan kepada perusahaan.

8. Pengintegrasian (integration)

Kegiatan untuk mempersatukan kepentingan perusahaan dan kebutuhan karyawan, agar tercipta kerjasama yang serasi dan saling menguntungkan. Perusahaan akan memperoleh laba sedangkan karyawan dapat memenuhi kebutuhan dari hasil pekerjaannya.

9. Pemeliharaan (maintenance)

Kegiatan untuk memelihara atau meningkatkan kondisi fisik, mental dan loyalitas karyawan agar mereka tetap mau bekerja sama sampai pensiun.

Kepuasan kerja adalah suatu sikap karyawan terhadap pekerjaan yang berhubungan dengan situasi kerja, kerjasama antar karyawan, imbalan yang diterima dalam kerja. Indikator kepuasan kerja meliputi Sutrisno (2009: 77) :

1. Kesukaan dengan pekerjaan

2. Kepuasan bekerja

3. Ketepatan pekerjaan bagi karyawan

4. Kepuasan atas hasil kerja yang dicapai karyawan

Kepuasan kerja pada dasarnya merupakan sesuatu yang bersifat individual. Setiap individu memiliki tingkat kepuasan yang berbeda sesuai dengan system nilai yang berlaku pada dirinya. Artinya bahwa kebutuhan selalu bertambah dari waktu ke waktu dan manusia selalu berusaha dengan kemampuannya untuk memuaskan kebutuhan tersebut (Rival dan Sagala, 2004).

Munandar, Sjabadhyni, Wutun (2004:73) mengemukakan bahwa kepuasan kerja adalah kondisi kesukaan atau ketidaksukaan menurut pandangan karyawan terhadap pekerjaannya. Koesmono (2005), mengemukakan bahwa kepuasan kerja dapat didefinisikan sebagai perasaan dan reaksi individu terhadap lingkungan pekerjaannya.

Kompensasi adalah segala sesuatu yang diterima karyawan sebagai balas jasa untuk kerja mereka. Indikator yang digunakan adalah : Handoko (2001 : 155):

1. Kompensasi yang diterima karyawan dalam bentuk non-finansial seperti memberikan penghargaan

2. Kompensasi yang diterima karyawan dalam bentuk finansial seperti memberikan gaji, upah, bonus dan tunjangan.

Pada dasarnya manusia bekerja juga ingin memeroleh uang untuk memenuhi kebutuhan hidupnya. Untuk itulah seorang karyawan mulai menghargai kerja keras dan semakin menunjukkan loyalitas terhadap perusahaan dan karena itulah perusahaan memberikan penghargaan terhadap prestasi kerja karyawan yaitu dengan jalan memberikan kompensasi. Salah satu cara manajemen untuk meningkatkan prestasi kerja, memotivasi dan meningkatkan kinerja para karyawan adalah melalui kompensasi (Mathis dan Jackson, 2000). Menurut Hasibuan $(2012 ; 127)$ bahwa faktor-faktor yang mempengaruhi kompensasi adalah sebagai berikut:

1. Penawaran dan Permintaan Tenaga Kerja. 
Jika pencarian kerja (penawaran) lebih banyak dari pada lowongan pekerjaan (permintaan) maka kompensasi relatif kecil. Sebaliknya jika pencari kerja lebih sedikit dari pada lowongan pekerjaan maka kompensasi relatif semakin besar.

2. Kemampuan dan Kesediaan Perusahaan.

Bila kemampuan dan kesediaan perusahaan untuk membayar semakin baik, maka tingkat kompensasi akan semakin besar, tetapi sebaliknya jika kemampuan dan kesediaan perusahaan untuk membayar kurang maka tingkat kompensasi relatif kecil.

3. Serikat Buruh / Organisasi karyawan.

Apabila serikat buruhnya kuat dan berpengaruh, maka tingkat kompensasi semakin besar, sebaliknya jika serikat buruh tidak kuat dan kurang berpengaruh, maka tingkat kompensasi relatif kecil.

4. Produktivitas Kerja Karyawan.

Jika produktivitas kerja karyawan baik dan tinggi, maka kompensasi akan semakin besar, sebaliknya apabila produktivitas kerjanya buruk serta rendah kompensasinya kecil.

5. Pemerintah dengan Undang-Undang dan Kepres.

Pemerintah dengan Undang-undang Kepres besarnya batas upah / balas jasa minimum. Penetapan pemerintah ini sangat penting supaya pengusaha jangan sewenang-wenang menetapkan besarnya balas jasa bagi karyawan karena pemerintah berkewajiban untuk melindungi masyarakat dari tindakan sewenang-wenang.

6. Biaya Hidup / Cost of Living.

Bila biaya hidup di daerah itu tinggi maka tingkat kompensasi / upah semakin tinggi. Tetapi sebaliknya karyawan yang biaya hidup di daerah itu rendah, maka tingkat kompensasi / upah relatif kecil.

Menurut Hasibuan (2012:121) beberapa tujuan dari Kompensasi Finansial antara lain adalah:

1. Ikatan kerja sama

Dengan pemberian kompensasi terjalin ikatan kerja sama formal antara majikan dan karyawan, dimana karyawan harus mengerjakan tugas dengan baik, sedangkan pengusaha/wajib membayar kompensasi sesuai perjanjian yang disepakati.

2. Kepuasan kerja

Dengan balas jasa karyawan akan dapat memenuhi kebutuhan fisik, status sosial dan egoistik sehingga ia memperoleh kepuasan kerja dari jabatan.

3. Pengadaan efektif

Jika program kompensasi ditetapkan cukup besar, maka pengadaan karyawan yang berkualitas untuk perusahaan itu akan lebih mudah.

4. Motivasi

Jika balas jasa yang diberikan cukup besar, manajer akan mudah memotivasi bawahannya.

5. Stabilitas karyawan

Dengan program kompensasi atas prinsip adil dan layak serta eksternal konsistensi yang kompentatif maka stabilitas karyawan lebih terjamin karena turnover relatif kecil.

6. Disiplin

Dengan pemberian balas jasa yang cukup besar maka disiplin karyawan semakin baik.

Mereka akan menyadari serta mentaati peraturan yang berlaku.

7. Pengaruh serikat buruh

Dengan program kompensasi yang baik pengaruh serikat buruh dapat dihindarkan dan karyawan akan berkonsentrasi pada pekerjaannya.

8. Pengaruh pemerintah 
Jika sesuai dengan undang-undang perburuhan yang berlaku (seperti batas upah minimum) maka intervensi pemerintah dapat dihindarkan. Tujuan pemberian balas jasa ini hendaknya memberikan kepuasan kepada semua pihak, karyawan dapat memenuhi kebutuhannya, pengusaha mendapat laba, peraturan pemerintah harus ditaati dan konsumen mendapat barang yang baik, harga yang pantas.

Karakteristik pekerjaan adalah sekumpulan tugas yang harus dilakukan sebagaimana yang dihasilkan oleh informasi analisis (Panudju, 2003) indikator yang digunakan adalah sebagai berikut :

1. Kebebasan untuk mengendalikan sendiri pelaksanaan tugasnya tanpa dibantu pimpinan.

2. Ketrampilan yang dibutuhkan untuk menyelesaikan tugas, ketrampilan dan variasi tugas.

3. Tingkat pemahaman prosedur kerja dan tingkat keterlibatan kerja.

Karakteristik pekerjaan merupakan bagian dari pengayaan pekerjaan. Sejumlah teori karakteristik pekerjaan yang berusaha mengidentifikasi karakteristik tugas dari pekerjaanpekerjaan, bagaimana karakteristik ini digabungkan untuk membentuk pekerjaan yang berbeda, serta hubungan dari karakteristik pekerjaan tersebut dengan kepuasan kerja telah dihasilkan.

Semangat kerja adalah kondisi kegairahan kerja yang dikembangkan oleh Lateiner (1985) dalam Irianto dan Dwiastuti (2005) terdapat empat dimensi yaitu :

1. Disiplin karyawan dalam pekerjaan.

2. Kerja sama antar karyawan yaitu rasa kerjasama antar karyawan.

3. Jaminan rasa aman dalam melaksanakan pekerjaan.

4. Perasaan puas hati terhadap apa yang diharapkan dengan kenyataan yang diterimanya.

Semangat kerja adalah sikap-sikap dari individu maupun kelompok terhadap lingkungan kerja dan terhadap kesukarelaannya untuk bekerjasama agar dapat mencurahkan kemampuannya secara menyeluruh sesuai dengan kebutuhan organisasi. (Nitisemito, 2001) Selain itu semangat kerja dapat didefinisikan sebagai suatu sikap dalam melakukan pekerjaan akan dapat diharapkan lebih baik dan lebih cepat.

Menurut Nawawi (2003), faktor-faktor yang mempengaruhi tinggi rendahnya semangat kerja adalah

1. Minat seseorang terhadap pekerjaan yang dilakukan. Seseorang yang berminat dalam pekerjaannya akan dapat meningkatkan semangat kerja

2. Faktor gaji atau upah tinggi akan meningkatkan semangat kerja seseorang

3. Status sosial pekerjaan. Pekerjaan yang memiliki status sosial yang tinggi dan memberi posisi yang tinggi dapat menjadi faktor penentu meningkatnya semangat kerja

4. Suasana kerja dan hubungan dalam pekerjaan. Penerimaan dan penghargaan dapat meningkatkan semangat kerja

5. Tujuan pekerjaan. Tujuan yang mulia dapat mendorong semangat kerja seseorang Semangat kerja tidak selalu ada dalam diri karyawan. Terkadang semangat kerja dapat pula menurun.

Kepuasan kerja pada dasarnya merupakan sesuatu yang bersifat individual. Setiap individu memiliki tingkat kepuasan yang berbeda sesuai dengan system nilai yang berlaku pada dirinya. Artinya bahwa kebutuhan selalu bertambah dari waktu ke waktu dan manusia selalu berusaha dengan kemampuannya untuk memuaskan kebutuhan tersebut (Rival dan Sagala, 2004).

Mangkunegara (2007:117-119) bahwa implikasi adanya ketidakpuasan adalah meningkatkan turnover, ketidakhadiran, maupun tingkat pekerjaan. Ini artinya bahwa kepuasan kerja akan mengurangi ketidak kerasanan karyawan dalam bekerja, meningkatkan jumlah 
kehadiran maupun kinerjanya. Veithzal (2004:480) menyebutkan adanya kepuasan kerja akan dapat menciptakan prilaku yang mempengaruhi fungsi-fungsi perusahaan. Oleh sebab itu adanya perbedaan kepuasan kerja antar unit-unit organisasi akan dapat digunakan mendeteksi penyebab persoalan seperti kenapa terjadi penurunan produktivitas.

Berdasarkan penjelasan diatas, maka konsep/kerangka pikir dalam penelitian ditunjukkan pada Gambar 1.
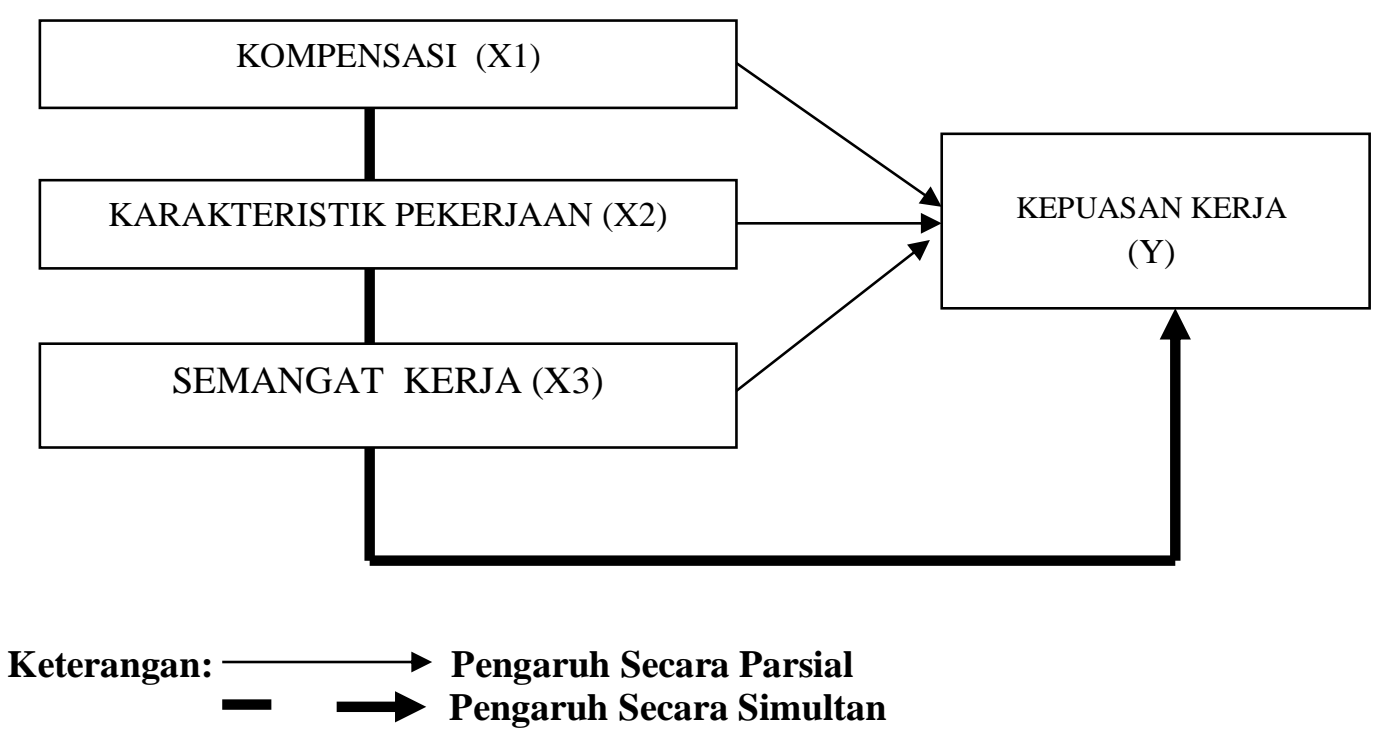

\section{Gambar 1. Kerangkà Konseptual dan Hipotesis}

\section{Metode Penelitian}

Desain penelitian yang digunakan adalah desain deskriptif analitik kuantitatif yang bertujuan menguraikan sifat dan karakteristik data-data atau variabel yang akan diuji, sehingga dalam penelitian ini digunakan untuk menganalisis data yang diperoleh, agar dapat diketahui pengaruh antar variabel bebas (Dependent) dan terikat ( Independent). Objek dalam penelitian ini adalah seluruh karyawan bagian produksi PT. Grafika Wangi Kalimantan.

Dalam rangka memperoleh data untuk penelitian ini digunakan teknik pengumpulan data adalah Observasi, Dokumentasi, Kuisioner. Sebelum dilakukan pengujian dengan analisis regresi, data penelitian diuji dengan uji asumsi klasik yang terdiri dari : uji normalitas, uji heterokedastisitas, dan uji multikolonieritas. Kemudian untuk pengujian hipotesis secara simultan menggunakan Uji F, dan untuk pengujian hipotesis secara parsial menggunakan Uji t. Sedangkan untuk menentukan variabel yang paling dominan mempengaruhi tingkat kepuasan kerja karyawan menggunakan nilai standrdized coefficient beta.

\section{Hasil Penelitian dan Pembahasan}

Langkah pertama dalam analisis ini adalah melakukan uji validitas dan reliabilitas. Penelitian ini dinyatakan valid dan reliabel seperti ditunjukkan pada Tabel 1 dan 2.

\section{Tabel 1. Rangkuman Hasil Uji Tes Validitas Kuisioner}




\begin{tabular}{cccccc}
\hline Variabel & Indikator & $\begin{array}{c}\text { Corrected item-total } \\
\text { correction }\left(\mathrm{r}_{\text {hitung }}\right)\end{array}$ & $<$ & $\mathrm{r}_{\text {tabel }}$ & Keterangan \\
\hline \multirow{2}{*}{$\begin{array}{c}\text { Kompensasi } \\
(\mathrm{X} 1)\end{array}$} & $\mathrm{X} 1.1$ & 0.858 & $>$ & 0.000 & Valid \\
\cline { 2 - 6 } & $\mathrm{X} 1.2$ & 0.831 & $>$ & 0.000 & Valid \\
\cline { 2 - 6 } & $\mathrm{X} 1.3$ & 0.876 & $>$ & 0.000 & Valid \\
\hline Karakteristik & $\mathrm{X} .2 .1$ & 0.866 & $>$ & 0.000 & Valid \\
\cline { 2 - 6 } Kerja $(\mathrm{X} 2)$ & $\mathrm{X} 2.2$ & 0.863 & $>$ & 0.000 & Valid \\
\cline { 2 - 6 } & $\mathrm{X} 2.3$ & 0.896 & $>$ & 0.000 & Valid \\
\hline Semangat & $\mathrm{X} 3.1$ & 0.822 & $>$ & 0.000 & Valid \\
\cline { 2 - 6 } Kerja $(\mathrm{X} 3)$ & $\mathrm{X} 3.2$ & 0.776 & & $>$ & Valid \\
\cline { 2 - 6 } & $\mathrm{X} 3.3$ & 0.793 & & & \\
\hline
\end{tabular}

Berdasarkan dari uji validitas menunjukkan bahwa nilai rhitung lebih besar dibanding nilai rtabel. Dengan hasil ini maka kuesioner yang digunakan oleh variabel Kompensasi, Karakteristik Pekerjaan dan Semangat Kerja dinyatakan valid sebagai alat ukur variabel.

Tabel 2. Hasil Uji Reliabilitas

\begin{tabular}{ccccc}
\hline Variabel & $\begin{array}{c}\text { Hasil Cronbach } \\
\text { Alpha }\end{array}$ & $><$ & $\begin{array}{c}\text { Standar } \\
\text { Reliabilitas }\end{array}$ & Keterangan \\
\hline Tangibles $(\mathrm{X} 1)$ & 0.908 & $>$ & 0.60 & Reliabel \\
\hline Reliability $(\mathrm{X} 2)$ & 0.922 & $>$ & 0.60 & Reliabel \\
\hline Responsiveness $(\mathrm{X} 3)$ & 0.847 & $>$ & 0.60 & Reliabel \\
\hline
\end{tabular}

Berdasarakan hasil uji reliabilitas menunjukkan nilai cronbach's alpha variabel Kompensasi, Karakteristik Pekerjaan dan Semangat Kerja di atas 0,60. Hal ini berarti kuesioner dari masing-masing indikator terbukti dapat dipercaya untuk digunakan sebagai alat ukur variabel.

Langkah selanjutnya adalah melakukan uji asumsi klasik, dengan urutan pengujian sebagai berikut:

1. Normalitas

Uji normalitas bertujuan untuk menguji apakah dalam model regresi, variabel pengganggu atau residual memiliki distribusi normal. Metode yang lebih handal adalah dengan melihat normal probability plot yang membandingkan distribusi kumulatif dari distribusi normal, seperti ditunjukkan pada Gambar 2

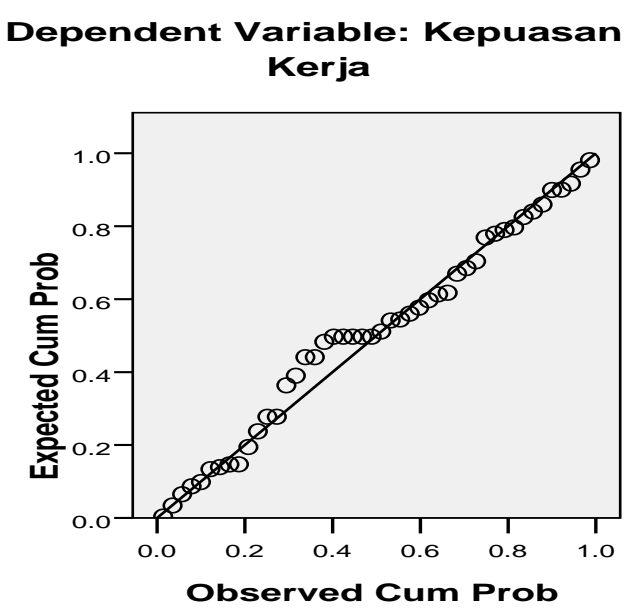

Gambar 2. Hasil Uji Normalitas 
Grafik normal probability plot memperlihatkan semua titik-titik berhimpit dan mengikuti garis diagonal, sehingga dapat disimpulkan bahwa model regresi telah memenuhi asumsi normalitas.

\section{Uji Multikolinearitas}

Hasil uji Multikolinearitas ditunjukkan pada Tabel 3. Karena nilai VIF dari masing-masing variabel bebas semuanya dibawah 5, maka penelitian ini bebas masalah multikolinearitas.

Tabel 3. Hasil Uji Multikolinieitas

\begin{tabular}{llrrr}
\hline Model & & \multicolumn{3}{c}{ Correlations } \\
\hline & & Part & Tolerance & VIF \\
\hline 1 & (Constant) & & & \\
\hline & Kompensasi & .220 & .418 & 2.394 \\
\hline & Karakteristik Pekerjaan & .053 & .312 & 3.204 \\
\hline & Semangat Kerja & .235 & .475 & 2.105 \\
\hline
\end{tabular}

Berdasarkan hasil uji multikolinearitas menunjukkan bahwa semua variabel independen yaitu Kompensasi, Karakteristik Pekerjaan dan Semangat Kerja mempunyai hubungan relasional semuanya tidak terjadi multikolinearitas, karena nilai tolerance yang didapat berada di atas 0,1, dan nilai VIF yang didapat berada di bawah 10 .

Langkah selanjutnya adalah pengujian analisis regresi berganda untuk melihat pengaruh dari semua variabel bebas terhadap produktivitas, yang ditunjukkan pada Tabel 4.

Tabel 4. Hasil Uji Regresi Linier Berganda

\begin{tabular}{llrrrrr}
\hline Model & & \multicolumn{2}{c}{$\begin{array}{l}\text { Unstandardized } \\
\text { Coefficients }\end{array}$} & \multicolumn{2}{c}{$\begin{array}{c}\text { Standardized } \\
\text { Coefficients }\end{array}$} \\
\hline & & \multicolumn{1}{c}{ B } & Std. Error & Beta & t & \multicolumn{1}{c}{ Sig. } \\
\hline 1 & (Constant) & .665 & .498 & & 1.333 & .190 \\
\hline & Kompensasi & .369 & .188 & .340 & 1.964 & .056 \\
\hline & Karakteristik & .098 & .206 & .095 & .473 & .639 \\
& Pekerjaan & & & & & \\
\hline & Semangat Kerja & .337 & .161 & .340 & 2.097 & .042 \\
\hline
\end{tabular}

Dari data hasil analisis regresi yang tertera pada tabel 4 dapat dibuat persamaan Regresi berikut:

$\mathrm{Y}=0,665+0,369 \mathrm{X} 1+0,098 \mathrm{X} 2+0,337 \mathrm{X} 3$

Uji - F digunakan untuk membuktikan adanya pengaruh antara variabel $\mathrm{X}$ yaitu Kompensasi (X1), Karakteristik Pekerjaan (X2) dan Semangat Kerja (X3) terhadap Y yaitu tingkat kepuasan kerja karyawan pada PT. Grafika Wangi Kalimantan secara simultan, pada tingkat sig. $\leq \square \square=0,06$.

Hasil uji - F sebesar 12.621 dan sig sebesar 0,000, nilai sig. ini dibawah $\alpha=<0,05$ menunjukkan bahwa hipotesis yang menyatakan variabel $\mathrm{X}$ yaitu Kompensasi (X1), Karakteristik Pekerjaan (X2) dan Semangat Kerja (X3) secara bersama-sama berpengaruh signifikan terhadap tingkat kepuasan kerja karyawan PT. Grafika Wangi Kalimantan. 
Untuk menguji pengaruhnya secara parsial digunakanlah uji t. Teknik uji t yang dilakukan yaitu dengan melihat nilai t signifikan pada hasil pengolahan data melalui SPSS. Dalam penelitian ini $\alpha$ yang digunakan yaitu sebesar 5\% $(0,05)$. Keputusannya, jika nilai t signifikan $<$ terhadap a maka $\mathrm{H} 0$ akan ditolak dan menerima Ha.

Tabel 5. Hasil Uji t

\begin{tabular}{llrrrrr}
\hline Model & \multicolumn{7}{c}{$\begin{array}{l}\text { Unstandardized } \\
\text { Coefficients }\end{array}$} & \multicolumn{2}{c}{$\begin{array}{c}\text { Standardized } \\
\text { Coefficients }\end{array}$} & & \\
\hline & & B & Std. Error & Beta & t & \multicolumn{1}{c}{ Sig. } \\
\hline 1 & (Constant) & .665 & .498 & & 1.333 & .190 \\
\hline & Kompensasi & .369 & .188 & .340 & 1.964 & .056 \\
\hline \multirow{2}{*}{$\begin{array}{l}\text { Karakteristik } \\
\text { Pekerjaan }\end{array}$} & .098 & .206 & .095 & .473 & .639 \\
& Semangat Kerja & .337 & .161 & .340 & 2.097 & .042 \\
\hline
\end{tabular}

Berdasarkan dari hasil uji - $\mathrm{t}$ diatas dapat dianalisa bahwa Pengaruh Variabel Kompensasi (X1) terhadap tingkat kepuasan kerja karyawan. Hasil nilai uji - $\mathrm{t}$ antara Kompensasi (X1) sebesar 1.964 dan sig sebesar 0,056. Dengan nilai dibawah $\alpha=<0,06$ maka menerima Ha1 yang menyatakan Kompensasi (X1) berpengaruh secara signifikan terhadap tingkat kepuasan kerja karyawan.

Pengaruh Variabel Karakteristik Pekerjaan (X2) terhadap tingkat kepuasan kerja karyawan. Hasil nilai uji - t antara Karakteristik Pekerjaan (X2) sebesar 0.473 dan sig sebesar 0,639 . Dengan nilai diatas tingkat signifikansi $\alpha=>0,06$ maka menerima H0 dan menolak Ha yang menyatakan Karakteristik Pekerjaan (X2) tidak berpengaruh signifikan terhadap tingkat kepuasan kerja karyawan.

Pengaruh Variabel Semangat Kerja (X3) terhadap tingtkat kepuasan kerja karyawan. Hasil nilai uji - $t$ antara Semangat Kerja (X3) sebesar 2.097 dan sig sebesar 0,042. Dengan nilai dibawah tingkat signifikansi $\alpha=<0,06$ maka menerima Ha3 yang menyatakan Semangat Kerja (X3) berpengaruh secara signifikan terhadap tingkat kepuasan kerja karyawan.

Menurut Malayu S.P Hasibuan (2012:118) mendefinisikan bahwa Kompensasi adalah semua pendapatan yang berbentuk uang, barang langsung atau tidak langsung yang diterima karyawan sebagai imbalan atas jasa yang diberikan kepada perusahaan. Sedangkan, menurut Veithzal Rivai (2011:357) menjelaskan bahwa, Kompensasi merupakan sesuatu yang karyawan dapatkan sebagai pengganti kontribusi jasa mereka pada perusahaan. Sistem imbalan bisa mencakup gaji, penghasilan, uang pensiun, uang liburan, promosi ke posisi yang lebih tinggi. Juga berupa asuransi keselamatan kerja, transfer secara horizontal untuk mendapat posisi yang lebih menantang atau ke posisi utama untuk pertumbuhan dan pengembangan berikutnya, serta berbagai macam bentuk pelayanan.

Jadi berdasarkan beberapa pengertian di atas secara umum dapat dikatakan bahwa kompensasi itu merupakan balas jasa yang diterima oleh karyawan sehubungan dengan pengorbanan yang telah diberikan kepada perusahaan. Pemberian kompensasi ini bisa diberikan langsung berupa uang maupun tidak langsung berupa uang dari perusahaan ke karyawannya.

Berdasarkan pernyataan diatas, dalam penelitian ini menunjukan bahwa kompensasi didalam melakukan pekerjaan yang diberikan oleh pihak perusahaan kepada karyawannya sangat mempengaruhi terhadap tingkat kepuasan kerja mereka dengan tingkat korelasi sebesar 0.615 atau sebesar $61.5 \%$, Jadi, dapat disimpulkan bahwa kompensasi berpengaruh secara parsial terhadap tingkat kepuasan kerja karyawan PT. Grafika Wangi Kalimantan.

Simamora (2004) mengemukakan bahwa karakteristik pekerjaan adalah suatu pendekatan terhadap pemerkaya pekerjaan (job enrichment). Program pemerkaya pekerjaan (job 
enrichment) berusaha merancang pekerjaan dengan cara membantu para pemangku jabatan memuaskan kebutuhan mereka akan pertumbuhan, pengakuan dan tanggung jawab. Pemerkaya pekerjaan menambahkan sumber kepuasan terhadap pekerjaan. Metode ini meningkatkan tanggung jawab, otonomi, dan kendali. Penambahan elemen tersebut kepada pekerjaan kadangkala disebut pemuatan kerja secara vertical (vertical job loading). Pemerkaya pekerjaan (job enrichment) itu sendiri merupakan salah satu dari teknik desain pekerjaan. Pendekatan klasik tentang desain pekerjaan yang diajukan Hackman dan Oldham (1980) dikenal dengan istilah teori karakteristik pekerjaan (job characteristic theory). Menurut Gitosudarmo dan Sudita (2008) Karakteristik pekerjaan mempunyai hubungan yang erat dengan desain pekerjaan. Desain pekerjaan berkaitan dengan struktur hubungan antar pribadi dari suatu pekerjaan dengan menentukan banyak keanekaragaman, tanggung jawab, signifikansi, dan otonomi pekerjaan.

Berdasarkan pernyataan diatas, dalam penelitian ini menunjukan bahwa Karakteristik Pekerjaan didalam melakukan pekerjaan yang diberikan oleh pihak perusahaan kepada karyawannya sangat mempengaruhi terhadap tingkat kepuasan kerja mereka dengan tingkat korelasi sebesar 0.598 atau sebesar 59.8\%, Jadi, dapat disimpulkan bahwa Karakteristik Pekerjaan berpengaruh secara parsial terhadap tingkat kepuasan kerja karyawan PT. Grafika Wangi Kalimantan.

Menurut Nitisemito (1992), semangat dan gairah kerja sulit untuk dipisahpisahkan meski semangat kerja memiliki pengaruh yang cukup besar terhadap semangat kerja. Dengan meningkatnya semangat dan gairah kerja, maka pekerjaan akan lebih cepat diselesaikan dan semua pengaruh buruk dari menurunnya semangat kerja seperti absensi dan selanjutnya akan dapat diperkecil dan selanjutnya menaikkan semangat dan gairah kerja yang berarti diharapkan juga meningkatkan produktivitas karyawan. Semangat kerja dapat diartikan sebagai semacam pernyataan ringkas dari kekuatan-kekuatan psikologis yang beraneka ragam yang menekan sehubungan dengan pekerjaan mereka. Semangat kerja dapat diartikan juga sebagai suatu iklim atau suasana kerja yang terdapat di dalam suatu organisasi yang menunjukkan rasa kegairahan di dalam melaksanakan pekerjaan dan mendorong mereka untuk bekerja secara lebih baik dan lebih produktif.

Berdasarkan pernyataan diatas, dalam penelitian ini menunjukan bahwa Semangat Kerja didalam melakukan pekerjaan yang diberikan oleh pihak perusahaan kepada karyawannya sangat mempengaruhi terhadap tingkat kepuasan kerja mereka dengan tingkat korelasi sebesar 0.612 atau sebesar 61.2\%, Jadi, dapat disimpulkan bahwa Semangat Kerja berpengaruh secara parsial terhadap tingkat kepuasan kerja karyawan PT. Grafika Wangi Kalimantan.

Hasil analisis data mengindikasikan bahwa variabel kompensasi, karakteristik pekerjaan dan semangat Kerja, secara simultan memberikan pengaruh yang signifikan terhadap tingkat kepuasan kerja karyawan PT. Grafika Wangi Kalimantan. Hal ini berarti bahwa tinggi rendahnya tingkat kepuasan kerja karyawan selama ini sangat dipengaruhi oleh ketiga variabel ini. Hal tersebut dipertegas pula dengan nilai koefisien determinasi hasil Adjusted R Square pada regresi pertama $=0,437$, artinya besarnya kemampuan variabel X yakni Kompensasi (X1), Karakteristik Pekerjaan (X2) dan Semangat Kerja (X3) dalam menjelaskan tingkat kepuasan kerja karyawan PT. Grafika Wangi Kalimantan sebesar 43.7\%. Dengan kata lain bahwa pengaruh langsung secara simultan dari ketiga variabel tersebut adalah positif dan siginifikan terhadap tingkat kepuasan kerja karyawan. Selain itu, tingkat keeratan hubungan secara simultan dari ketiga variabel ini yakni Kompensasi (X1), Karakteristik Pekerjaan (X2) dan Semangat Kerja (X3) terhadap tingkat kepuasan kerja karyawan adalah menunjukkan bahwa variabel Kompensasi (X1), Karakteristik Pekerjaan (X2) dan Semangat Kerja (X3) memiliki keeratan hubungan dengan peningkatan atau penurunan tingkat kepuasan kerja karyawan.

Hasil penelitian ini juga diperkuat denga teori yang dinyatakan oleh Simamora (2004) bahwa dimana tugas-tugas dikombinasikan untuk menciptakan pekerjaan individu yang 
mempunyai pengaruh individu yang mempunyai pengaruh langsung terhadap kinerja dan kepuasan karyawan.

Komponen dasar struktur organisasi dan merupakan alat untuk mencapai tujuan organisasi. Oleh karena itu pekerjaan sedemikian rupa dalam rangka mencapai efisiensi teknis dan produktivitas bahkan perancangan pekerjaan merupakan proses yang ditentukan dan diciptakan oleh kompensasi, karakteristik pekerjaan dan semangat kerja melalui nilai standardized coefficients yang terdapat pada tabel 5.8, dapat diketahui bahwa diatara ketiga variabel yang mempengaruhi kepuasan kerja, variabel kompensasi memberikan pengaruh yang lebih besar dengan tingkat koefisien sebesar 0.369 atau sebesar 36.9\% terhadap tingkat kepuasan kerja, sebaliknya variabel karakteristi pekerjaan memberikan pengaruh yang paling kecil terhadap tingkat kepuasan kerja karyawan PT. Grafika Wangi Kalimantan yakni sebesar 0.098 atau sebesar $9.8 \%$.

\section{Kesimpulan}

Hasil analisis data mengindikasikan bahwa variabel kompensasi, karakteristik pekerjaan dan semangat Kerja, secara simultan memberikan pengaruh yang signifikan terhadap tingkat kepuasan kerja karyawan PT. Grafika Wangi Kalimantan. Berdasarkan pada temuan tersebut,adapun saran yang perlu direkomendasikan dalam meningkatkan kepuasan kerja karyawan Faktor penting yang harus diperhatikan oleh perusahaan terutama pimpinan harus memperhatikan ketiga variabel ini yakni kompensasi, karakteristik pekerjaan dan semangat kerja. Terlebih lagi pada faktor kompensasi serta karakteristik pekerjaan karena dari dua hal ini sangat mempengaruhi tingkat kepuasan kerja karyawan. Kompensasi yang diberikan harus sesuai dengan apa yang telah mereka kerjakan dan karakteristik pekerjaan juga harus sesuai dengan bidang yang mereka kuasai.

Meskipun secara analisis statistik semangat kerja kecil pengaruhnya terhadap tingkat kepuasan kerja karyawan, akan tetapi faktor ini juga harus mendapat perhatian yang lebih dari perusahaan dan pimpinan. Karena tanpa semangat kerja maka akan menurunkan tingkat

kepuasan kerja karyawan. Hendaknya hal ini harus ditingkatkan lagi supaya apa yang menjadi visi dan misi perusahaan bisa tercapai.

\section{DAFTAR PUSTAKA}

As'ad M. 2005. Psikologi Industri . Yogyakarta: Liberty

Bejo Siswanto. 2004. Manajemen Sumber Daya Manusia. Cetakan Pertama. STIE YKPN. Yogyakarta.

Brahmasari \& Suprayetno.2008. Pengaruh Motivasi, Kepemimpinan dan Budaya Organisasi terhadap kepuasan kerja Karyawan serta Dampaknya pada Kinerja Perusahaan (Studi Kasus pada PT Pei Hai International Wiratama Indonesia) Jurnal Ekonomi Manajemen Vol. VII No. 2 Sepetember 2008.

Bangun, Wilson. (2012). Manajemen Sumber Daya Manusia. Jakarta: Erlangga.

Dharma, Agus, 2001. Pengukuran Kinerja Karyawan, Jakarta: Rineka Cipta

Darmawan, Didit. 2007. Teori Motivasi. Metromedia Education. Surabaya

Flippo, Edwin B, 2005. Manajemen Personalia (Terjemahan Hani Handoko T) Erlangga, Jakarta.

Gitosudarmo Indriyo dan I Nyoman Sudita, 2008, Perilaku Keorganisasian, Yogyakarta: BPFE. Hackman.R.J.,and Oldham.R.G.,1980. Work Redesign. Wesley Publishing Company,Inc Hasibuan, Malayu. 1999. Manajemen Sumber Daya Manusia. Bina Aksara. Jakarta

Hakim, Abdul. 2006. Analisis Pengaruh Motivasi, Komitmen Organisasi Dan Iklim Organisasi Terhadap Kinerja Pegawai Pada Dinas Perhubungan Dan Telekomunikasi Propinvsi Jawa Tengah. Jurnal Riset Dan Bisnis 
Indonesia (JRBI). Vol. 2. No. 2. Juli. Hal. 165 - 180. Unnisula. Semarang.

Handoko, Hani. 2008. Manajemen Sumber Daya Manusia. Yogyakarta

Hasibuan, Malayu. 2008. Manajemen Sumber Daya Manusia. Penerbit PT. Bumi Aksara. Jakarta

Hamzah. 2009. Teori Motivasi dan pengukurannya, (Jakarta : PT Bumi Aksara )

Herlina, Retnasari, 2010, Pengaruh Karakteristik Pekerjaan dan Kepuasan Kerja terhadap Kinerja Karyawan AJB Bumi Putra Kendari. Skripsi, Kendari: Fekon Unhalu. Indriantoro, Nur, dan Bambang Supomo. 1999. Metodologi Penelitian Bisnis. BPFE. Yogyakarta

James A. F. Mathis. Alfonsus Jackson, 2006, Manajemen Jilid I, Edisi 8, Erlangga, Jakarta.

Karismawan, Alex. 2005. Manajemen Sumber Daya Manusia. PT. Gramedia Widiasarana Indonesia. Jakarta.

Luthans, Fred. 1998. Organizatinal Behavior. Eight Edition. Irwin/McGraw-Hill. New York. United Stated of America.

Luthans, Fred. 2011. Organizational Behavior : An Evidence-Based Approach.McGraw-Hill. New York.

Mathis L. and Jhon Jackson, 2001, Manajemen Sumber Daya Manusia (Human Resource Management), PT. Salemba Emban Patria, Jakarta.

Malhotra, Naresh, K. 1999. Marketing Research: An Applied Orientation, Third Edition. Upper Saddle. Pientice Hall, Inc, New Jersey.

Mangkunegara, 2000. Manajemen Sumber Daya Manusia. PT Erlangga : Jakarta

Mangkunegara, 2005. Manajemen Sumber Daya Manusia. PT Erlangga : Jakarta

Munandar. 2004. Manajemen Sumber Daya Manusia. Erlangga : Jakarta.

Murdjianto. 2001. Manajemen Sumber Daya Manusia. Bina Atmaja : Bandung.

Nitisemito, Alex S. 1992. Manajemen Personalia. Penerbit Ghalia. Cetakan Delapan. Jakarta

Nitisemito, Andi. 2001. Manajemen Sumber Daya Manusia. PT Erlangga: Jakarta

Notoatmodjo, Suyadi. 2001. Manajemen Kinerja Karyawan. BPFE Yogyakarta

Nawawi, Hadari. 2003. Manajemen Strategik Organisasi Non Profit Bidang Pemerintahan. Gajah Mada University Press. Yogyakarta.

Robbins, Stephen P. 2006. Perilaku Keorganisasian. Jilid 1 Edisi 10, PT Indeks Kelompok Gramedia. Jakarta.

Rivai, Veithzal dan Ella Juavani Sagala. 2005. Manajemen Sumber Daya Manusia. Jakarta

Rivai, Veithzal dan Ella Juavani Sagala. 2008. Manajemen Sumber Daya Manusia. Jakarta

Steers, M. Richard et al. 1995. Organizational Effectiveness : A Behavioral View. Goodyear Publishing Company Inc. Santa Monica. California. United Stated of America

Setiawan E. 2005, Metodologi Bisnis, Yayasan Widya Manggala Indonesia : Semarang.

Simamora, Henry. 2002. Manajemen Sumber Daya Manusia. STIE YKPN. Yogyakarta

Silvana, Budiatmo, 2002, Manajemen Sumber Daya Manusia. Yogyakarta: BPFE. UGM.

Sutrisno, Edy 2008, Manajemen Sumber Daya Manusia, Prenada Media Group, Jakarta.

Sutrisno, Edy 2009, Manajemen Sumber Daya Manusia, Prenada Media Group, Jakarta.

Wexley, K. N \& Yukl, G. A. 2003. Perilaku Organisasi dan Psikologi Personalia. Bina Aksaran. Jakarta.

Zainun, Buchari. 1991. Administrasi Dan Manajemen Kepegawaian Pemerintah Negara Indonesia. Gunung Agung. Jakarta 